\title{
HISTORIA GOSPODARCZA CHIN OKRESU PRZEDKOMUNISTYCZNEGO. PRZEKSZTAŁCENIA WEWNECTRZNE I MIĘDZYNARODOWE STOSUNKI GOSPODARCZE
}

Chiny, będąc jedną z najstarszych cywilizacji świata, w swych dziejach do 1949 r. przeżywały okresy świetności, które przerywały lata wojen, grabieży, podziałów i utraty niepodległości. Kraj przez prawie 4 tys. lat budował potęgę militarną i ekonomiczna. Do początku XV w. gospodarka chińska przewyższała zaawansowaniem resztę świata, lecz od rewolucji przemysłowej pozycja geoekonomiczna kraju osłabiała się. W okresie pomiędzy panowaniem dynastii Zhou a Qing obszar imperium chińskiego zwiększył się ponad 27-krotnie, natomiast powierzchnia ziem uprawnych wzrosła prawie 13 razy ${ }^{1}$.

W historii rozwoju społeczno-gospodarczego Chin przedkomunistycznych, przed 1 października 1949 r. można wyodrębnić dwa długie etapy. Pierwszy obejmuje czasy od około 221 r. p.n.e. ${ }^{2}$ do początku XIX w. n.e., kiedy w Chinach dominowała gospodarka oparta na rolnictwie, a prowadzona polityka skupiała się na ekspansji militarnej. W ramach tego stadium można wyróżnić fazy intensywnego rozwoju gospodarczego przypadające na panowanie dynastii Tang (618-907 r. n.e.) i Song (960-1279 r. n.e.), przeplatane długimi okresami rozwoju ekstensywnego. Drugi etap historii gospodarczej przedkomunistycznych Chin trwał od zapoczątkowanej w Europie rewolucji przemysłowej do proklamacji Chińskiej Republiki Ludowej (ChRL) i zapisał się w historii Państwa Środka pod znakiem szybkiego załamania potęgi ekonomicznej.

Celem artykułu jest zaprezentowanie poszczególnych etapów rozwoju gospodarki Chin i jej powiązań ze światem przed okresem realnego socjalizmu. W pierwszej części opracowania ukazano wewnętrzne procesy zmian w gospodarce, w drugiej skoncentrowano się na identyfikacji powiązań handlowych i inwestycyjnych ze światem. Ze względu na ograniczoną objętość artykułu zaprezentowany materiał ma charakter wstępu do pogłębionej analizy historii gospodarczej Chin przed 1949 r.

\footnotetext{
J.C.H. Chai, An Economic History of Modern China, Massachusetts 2011, s. 7.

2 Zapoczattkowanie tego etapu zbiega się z powołaniem pierwszego cesarza Chin z dynastii Qin. O. Weggel, Chiny, Warszawa 2006, s. 252.
} 


\section{Wewnętrzne procesy rozwoju gospodarki Chin przedkomunistycznych}

W pierwszych wiekach istnienia (rządy dynastii Shang i Zhou) Chiny były rozwiniętym absolutystycznym krajem rozbitym na kilkadziesiąt państewek. Władza państwa była zdecentralizowana, a system ekonomiczny przypominał europejski feudalizm³ W tym okresie utworzono system podatkowy, kodeks karny i regularną armię. Krajem rządzili cesarze mianujący siebie „Synami Nieba”. Tytuł ten funkcjonował do 1912 r. ${ }^{4}$

Dzieje Chin do początku XIX w. n.e. upływały na walkach wewnętrznych, podbojach militarnych sąsiednich terenów, rozpadzie kraju na mniejsze państewka i jego ponownym jednoczeniu ${ }^{5}$, ożywionych kontaktach handlowych z zagranica, rozwoju nauki, techniki i literatury, powstawaniu szkół filozoficznych i wkraczaniu buddyzmu do kultury chińskiej. We wczesnej fazie rozwoju państwa tempo wzrostu populacji i produkcji na osobę nie zmieniało się. Gospodarka opierała się na rolnictwie. W ubogim w obszary zdatne do upraw kraju realizowano wzrost produkcji poprzez jej intensyfikację. W VIII w. p.n.e. 3/4 ludności zamieszkiwało Chiny północne, gdzie panowały dogodne warunki do uprawy pszenicy i prosa. Rozwojowi rolnictwa za czasów dynastii Han (III w. p.n.e. - III w. n.e.) sprzyjał postęp agrotechniczny. Rozbudowano system irygacji, kontrolowano stan wód, stosowano narzędzia rolnicze, a nawet żelazne pługi ciagnięte przez zwierzęta ${ }^{7}$.

W analizowanym okresie dokonano wielu odkryć naukowych i opracowano wynalazki techniczne. Już w VII w. p.n.e. stosowano żelazo (głównie do wyrobu narzędzi rolniczych, a później broni) oraz korzystano z technik odlewnictwa. Chińskie innowacje często adaptowano lub odkrywano z wielowiekowym opóźnieniem w zachodnich mocarstwach ${ }^{8}$. Natomiast chińska produkcja rosła na skutek stopniowego

3 S.W. Mosher, Hegemon. Droga Chin do dominacji, Warszawa 2007, s. 40.

4 J. Chinnery, Rola państwa [w:] Chiny. Kraj Niebiańskiego Smoka, red. E.L. Shaughnessy, Warszawa 2006, s. 44-45; A. Zwoliński, Chiny. Historia. Teraźniejszość, Kraków 2007, s. 10-13.

5 Punktem zwrotnym w historii kraju stało się wstąpienie na tron Qin Shi Huanga Di (221210 r. p.n.e.), który zjednoczył kraj i wprowadził ideę Wielkich Chin. Swoją władzę opierał na zasadach legizmu. Cesarz stworzył podwaliny systemu zarządzania państwem, który później rozbudowały następne dynastie. Podstawą doktryny było zupełne zwierzchnictwo władcy oraz osłabienie arystokracji i podporządkowanie sobie ludu. Wprowadzono surowe i szczegółowe regulacje dotyczące każdej sfery życia. Dynastia Qin stworzyła kraj totalitarny. W tym okresie rozpoczęto łączenie murów obronnych podbitych państw i zapoczątkowano budowę Wielkiego Muru. Na Qin Shi Huangu Di wzorował się Mao Zedong.

6 J. Skodlarski, R. Matera, Gospodarka światowa. Geneza i rozwoój, Warszawa 2004, s. 20.

7 W. Rodziński, Historia Chin, Wrocław-Warszawa-Kraków 1974, s. 45.

8 R. Cameron, L. Neal, Historia gospodarcza śniata. Od paleolitu do czasów najnowszych, Warszawa 2004, s. 92; R. Sławiński, Historia Chin i Tajwanu, Warszawa 2002, s. 23-24, 58; W. Rodziński, Historia Chin..., s. 44-45; D.S. Landes, Bogactwo i nedza narodów, Warszawa 2000, s. 72-75, 77. 
wprowadzania specjalizacji w rzemiośle, co dało podstawy rzemiosłu artystycznemu i sztuce chińskiej ${ }^{9}$. Rozwój gospodarki doprowadził do upowszechnienia się pieniądza i zmiany jego formy. Z pieniądza w postaci jedwabiu i sztabek cennych metali zaczęto przechodzić na pieniądz miedziany. Z czasem przybrał on formę okragłej dziurkowanej monety, która funkcjonowała przez ponad 2 tys. lat. W okresie panowania dynastii Han, w około 120 r. p.n.e., zaczęto używać pieniądza pergaminowego, który po wynalezieniu papieru zmienił swą formę właśnie na papierową ${ }^{10}$.

Za okres świetności Państwa Środka uznaje się rządy dynastii Tang i Song ${ }^{11}$. Ród Tang przejął państwo podzielone, lecz z rozwiniętymi nowoczesnymi metodami produkcji. Zjednoczenie Chin pozwoliło na pełne wykorzystanie potencjału gospodarki i stworzenie największego wówczas kraju azjatyckiego. Stworzono pionierski model zarządzania państwem, który funkcjonował do 1905 r. Dynastia Tang zastapiła rządy rodów arystokratycznych wysoko wyszkoloną klasą biurokratyczna, którą wyłaniano w drodze specjalnych egzaminów sprawdzających merytoryczną wiedzę z zakresu pism konfucjańskich. Elita rządząca powszechnie używała języka pisanego. Ponadto zreformowano organizacje państwowa. System administrowania krajem cechowała efektywność i tanie utrzymanie w porównaniu z wielowarstwowymi strukturami rządów w feudalnej Europie i Japonii. W Chinach elita rządząca stanowiła 3\% społeczeństwa, podczas gdy w Japonii dwa razy więcej. Fiskalne obciążenia wynikające $z$ utrzymania władzy stanowiły 5\% chińskiego PKB, natomiast w Japonii 25\% PKB. Warto zaznaczyć, że koszty administracji w Chinach stopniowo rosły w wyniku tzw. opłat zwyczajowych, co w ostatecznym rozrachunku podnosiło utrzymanie klasy rządzącej do około $15 \% \mathrm{PKB}^{12}$.

Za rządów dynastii Tang i Song kulminacyjny punkt rozwoju osiągnęły: wynalazczość, sztuka, techniki organizacji społecznej i sprawowania władzy oraz filozofia. Kraj stał się pierwszą potęga morską świata i pozycję tę utrzymywał przez kilkaset lat. Wzrost gospodarki stymulowało rolnictwo, które przechodziło proces transformacji i osiagnęło szczyt rozwoju. Stopniowo odchodzono od uprawy tradycyjnych zbóż na rzecz ryżu sianego na bagnistych terenach nadrzecznych. Populacja powiększała się w dynamicznym tempie i przekroczyła $100 \mathrm{mln}$ (w stosunku do około $55 \mathrm{mln}$ pod koniec $\mathrm{X}$ w. $)^{13}$. Korzystne warunki topograficzne i odpowiedni klimat

9 W. Rodziński, Historia Chin ..., s. 45-48.

10 W. Morawski, Historia banknotów na świecie, „Jak w Banku”, lipiec-sierpień 2008, s. 25; A. Mikołajczyk, Leksykon numizmatyczny, Warszawa 1994, s. 74-75, za: J. Skodlarski, R. Matera, Gospodarka światowa..., s. 22.

11 Między rządami Tang i Song nastąpiło największe w ówczesnych dziejach załamanie gospodarcze i rozpad Chin.

12 A. Maddison, Contours of the World Economy, I-2030 AD. Essays in Macro-Economic History, Oxford-New York 2007, s. 159; J.K. Fairbank, Historia Chin. Nowe spojrzenie, przeł. T. Lachowska, Z. Słupski, Gdańsk 1996, s. 79, 86-88; O. Weggel, Chiny..., s. 253.

13 Dane odnoszące się do wielkości populacji Chin pod koniec XIII w. różnią się w zależności od źródła. Maddison oszacował liczbę ludności na $100 \mathrm{mln}$, co stanowiło ponad 26\% populacji 
przesądziły o atrakcyjności południowych wybrzeży rzeki Jangcy i przekształciły je w centrum kraju. Nastapiła masowa migracja ludności z północy na południe. Pod koniec XIII w. około $60-85 \%$ populacji Chin zamieszkiwało południe rzeki Jangcy i trudniło się uprawą ryżu. Koncentracja populacji i produkcji spowodowała izolację oraz niski poziom rozwoju pozostałych regionów kraju.

W walce $z$ dysproporcjami rozwojowymi pomocne okazało się upowszechnianie piśmiennictwa, które ułatwiało dyfuzję technologii. Ponadto rozwinęły się: włókiennictwo, wydobycie soli i metali, hutnictwo, garncarstwo i przemysł papierni$\mathrm{czy}^{14}$. Do produkcji wprowadzono specjalizację. Rozwijał się handel. Wybudowano kanał pomiędzy głównymi chińskimi rzekami, co usprawniło handel wewnętrzny, a rozbudowa żeglugi i stosowanie nowych technik budowy statków wspierały kontakty kupieckie ${ }^{15}$. Jednak za doskonaleniem budowy statków przemawiały bardziej względy bezpieczeństwa (ochrona przed najazdami mongolskimi) niż potrzeba prowadzenia wymiany handlowej z zagranica.

Poprawiła się wydajność i jakość siły roboczej. Standard życia ludności podnosił się. Oparcie produkcji na wyrobach bawełnianych poskutkowało poprawą higieny codziennego życia. Wprowadzono reformy podatkowe, pańszczyznę zastapiono czynszem, budowano spichlerze na wypadek nieurodzaju oraz utworzono bank państwowy udzielający niskooprocentowanych pożyczek chłopom ${ }^{16}$. Władze, świadome roli rolnictwa w tworzeniu PKB, wspierały jego rozwój przez upowszechnianie w formie pisanej nowinek technologicznych, wydawanie podręczników dotyczących upraw czy sprowadzanie nowych odmian zbóż, co zwielokrotniało zbiory. Zaczęto uprawiać herbatę, bawełnę, sorgo, kukurydzę, ziemniaki, bataty, orzeszki ziemne i tytoń.

Jednak liczne innowacje i ogólny postęp nie zmieniły charakteru chińskiej gospodarki z agrarnego na industrialny. W gospodarce dominowało rolnictwo, w dużej mierze dzięki wsparciu wyedukowanej klasy rządzącej. Szybko rozwijał się przemysł, ale nie na tyle, aby stać się najważniejszym działem gospodarki. O poziomie rozwoju przemysłu w relacji do krajów Zachodu może świadczyć fakt, że pod koniec XI w. produkowano 125 tys. ton surówki. Taki sam poziom produkcji Wielka Brytania osiagnęła dopiero 700 lat później ${ }^{17}$. Kres epoki prosperity nastąpił wraz z zajęciem kraju przez wojska mongolskie (1260-1368).

świata, Zhao i Xie piszą o $108 \mathrm{mln}$, Durand wskazywał na $123 \mathrm{mln}$, a Elvin $140 \mathrm{mln}$. W. Zhao, S. Xie, Zhongguo Renkou Shi (Population History of China), Beijing 1988; M. Elvin, The Pattern of the Chinese Past, London 1973; J.D. Durand, The Population Statistics of China A.D. 2-1953, „Population Studies", March 1960, za: A. Maddison, Chinese Economic Performance in the Long Run, Paris 1998, s. $20,24$.

14 B. Zientara, Historia powszechna średnioniecza, Warszawa 1968, s. 112.

15 P.J. Golas, Technika i nauka [w:] Chiny. Kraj Niebiańskiego Smoka..., s. 22, 174.

16 J.C.H. Chai, An Economic History..., s. 20-21.

17 D.S. Landes, Bogactwo i nedza..., s. 78. 
Najazd Mongolii zahamował szybkie tempo, w jakim rozwijała się gospodarka Państwa Środka. W trakcie panowania dynastii mongolskiej Yuan populacja Chin spadła o 1/3 wskutek epidemii dżumy i barbarzyńskiej polityki najeźdźcy ${ }^{18}$. Pomimo trudnego okresu dla chińskiej gospodarki w 1300 r. kraj był światowym liderem pod względem PKB na osobę ${ }^{19}$.

Wraz z ustappieniem rządów Mongołów w Chinach zaszły głębokie przemiany demograficzne i ekonomiczne. Powrót na tron chińskiej dynastii Ming (1368-1644) pozwolił na przywrócenie stabilizacji gospodarczej i politycznej. Populacja wzrosła czterokrotnie, a wraz nią poziom PKB per capita ${ }^{20}$. Niektórzy autorzy nazywaja te epokę wczesną rewolucją przemysłową opartą na produkcji żelaza, inni wskazuja na ogromną rolę rozwoju krajowego rynku ryżu ${ }^{21}$. Technologia i kultura ponownie osiagnęły wysokie zaawansowanie, a rolnictwo znajdowało się w stadium dynamicznego rozwoju ${ }^{22}$. Intensywnie rozwijały się cesarskie i prywatne manufaktury produkujące tkaniny jedwabne, bawełniane i ceramikę oraz przemysł wydobywczy, głównie metali kolorowych, rud żelaza, soli i węgla kamiennego. W rzemiośle istniało aż 200 specjalizacji ${ }^{23}$.

Potęga Chin zachwiały europejskie odkrycia geograficzne z XV w. Również Chińczycy na krótko zintensyfikowali swoje morskie wyprawy. W latach 1405-1431 zorganizowali przynajmniej siedem wypraw na wody Indonezji i Oceanu Indyjskiego. Ich celem było zasygnalizowanie istnienia Państwa Środka i złupienie rzadkich okazów (egzotycznych zwierząt, klejnotów, substancji pochodzenia zwierzęcego, roślinnego i mineralnego). Statkami wywożono z Chin najcenniejsze towary (jedwab i porcelanę), jednak trudno rozstrzygnać, czy dobra te zamierzano sprzedać na wolnym rynku, czy raczej oddać w darze władcy. Z czasem kupcy chińscy zaczęli organizować indywidualne wyprawy. $\mathrm{Na}$ początku XV w. masowo budowano i remontowano okręty, aby po kilkudziesięciu latach zaprzestać prac i zniszczyć flotę ${ }^{24}$. W tym czasie mocarstwa europejskie coraz częściej ujawniały zamiary kolonizacyjne w stosunku do Chin, podczas gdy kraj dokonywał samorozbrojenia i stopniowo zamykał się na światowe nowinki technologiczne i naukowe. Koniec panowania

18 Niszczono miasta i wsie, zaniechano prac hydraulicznych wokół Wielkiego Kanału, próbowano zniszczyć kulturę chińska. Jednak Mongołowie nie potrafili się przeciwstawić tradycji chińskiej i stopniowo doszło do ich asymilacji z podbitym narodem.

19 A. Maddison, Contours of the World..., s. 161.

20 Przyczyny wzrostu liczby ludności nie zostały jednoznacznie wytłumaczone przez ekonomistów i historyków, ponieważ nie ma wiarygodnych danych z tamtego okresu.

21 A. Maddison, Chinese Economic Performance..., s. 25.

22 W. Rodziński, Historia Chin ..., s. 314-315.

23 J. Skodlarski, R. Matera, Gospodarka światowa..., s. 98.

${ }^{24}$ Od 1436 r. zakazano zatrudniania nowych rzemieślników w stoczniach. W 1500 r. groziła nawet kara śmierci za zbudowanie statku mającego ponad dwa maszty, a ćwierć wieku później nakazano zniszczyć wszystkie istniejące statki pełnomorskie. D.S. Landes, Bogactwo i nędzৃa..., s. $118-121$. 
dynastii Ming, przypadający na pierwszą połowę XVII w., upłynął na zmaganiach się z ingerencją państw europejskich i kryzysem gospodarczym ${ }^{25}$.

Osłabienie Chin wykorzystała Mandżuria, podbijając kraj na ponad 250 lat (1644-1911) ${ }^{26}$. W okresie rządów mandżurskiej dynastii Qing zmagano się z eksplozją demograficzną, epidemiami dżumy, odry i ospy, głodem, powstaniami zbrojnymi oraz dalszą ingerencją mocarstw zachodnich w politykę wewnętrzną i handel zagraniczny. Choroby przywieziono do Chin z Europy. W niektórych częściach kraju w wyniku zaraz zmarło 2/3 ludności. Przyczyną niedostatku żywności okazało się przerwanie przez władze prac hydraulicznych, w wyniku czego nie kontynuowano budowy tam na Rzece Żółtej. Skutkiem tego zaniechania okazała się zmiana biegu rzeki i zamulenie Wielkiego Kanału, którego nie można było dłużej używać w celu transportu zbóż do Pekinu. Za przyczynę zubożenia można uznać również przesunięcie się głównych szlaków handlowych z pustynnych obszarów na trawiaste stepy, co spowodowało wyludnienie ${ }^{27}$.

Upadek potęgi Państwa Środka nastąpił wraz przechodzącą przez Zachód falą rewolucji przemysłowej i naukowej. Gospodarki Europy Zachodniej modernizowały się, podczas gdy Chiny pozostawały w izolacji od odkryć przemysłowych i naukowych ${ }^{28}$. Wzrost gospodarczy realizowano dzięki ekstensywnemu rolnictwu oraz fabrycznemu przemysłowi włókienniczemu zlokalizowanemu w Szanghaju i innych wybranych miastach portowych. Przedsiębiorczość była ograniczana przez system biurokratyczny. Opierając się na restrykcyjnych regulacjach prawnych, nie udzielano klasie średniej zezwoleń na zakładanie przedsiębiorstw przemysłowych na wzór europejski, a zmiany właściciela i przejęcia już funkcjonujących przedsiębiorstw odbywały się w ramach sektora państwowego. Wysocy urzędnicy państwowi i uprzywilejowane grupy społeczne dążyły do zachowania status quo i monopolu na przejmowanie zysków z aktywności ekonomicznej. Władza unikała wprowadzania praw zabezpieczających działalność przedsiębiorstw prywatnych, banków, kupców i drobnych handlowców oraz nakładała ograniczenia na tego rodzaju działalność.

Odmienną wizję polityki ekonomicznej Chin w XIX w. miały mocarstwa europejskie, które były w znacznej mierze uzależnione od wymiany towarowej z tym

25 Głównymi przyczynami kryzysu końca XVII w. były: stopniowa izolacja na arenie międzynarodowej, nielegalny handel, piractwo oraz wojna z Japonią. Ibidem, s. 380, 384.

${ }^{26}$ Cesarstwo Chińskie utworzone przez Mandżurów okazało się jedynym tego rodzaju tworem, który przetrwał do czasów nowożytnych. Dynastia Qing, pomimo że traktowana przez Chińczyków jako „obca”, odegrała zasadniczą rolę w krzewieniu chińskiego stylu życia i filozofii konfucjańskiej. Mandżurów spotkał los podobny jak Mongołów - zostali „wchłonięci” przez kulturę chińską. Ibidem, s. 388.

27 V. Hansen, The Open Empire: A History of China to 1600, New York 2000, za: J. Lovell, Wielki Mur Chinski. Chiny kontra swriat. 100 p.n.e.-2000 n.e., przel. G. Siwek, Warszawa 2007, s. 192-193.

28 K. Pomeranz, The Great Divergence, Princeton, New Jersey 2000, s. 43-68. 
azjatyckim państwem ${ }^{29}$. Kraje Europy próbowały narzucić Chinom ustrój kapitalistyczny na wzór Japonii. Kiedy „pokojowe” naciski obcych mocarstw nie przyniosły rezultatów, zmusiły Chiny do otwarcia portów na handel zagraniczny. Państwo uchroniło się od rozbioru, ale jego gospodarka podupadała, a wraz z nią obniżał się standard życia ludności. Istniejący system biurokratyczny okazał się niezdolny do wprowadzenia reform modernizacyjnych. System edukacji nadal bazował na klasyce i ortodoksyjnej biurokracji, dlatego państwo nie mogło stworzyć podstaw modernizacji gospodarki. Po klęsce w wojnie z Japonią (1894-1895) powstał nawet ruch reformatorski pod nazwą Sto Dni Reform. W stowarzyszeniu znajdowali się głównie chińscy intelektualiści - zwolennicy okcydentalizacji. Zaproponowali pakiet dekretów opartych w dużej mierze na doświadczeniach Japonii i innych krajów kapitalistycznych. Wprowadzenie 40 cesarskich dekretów, dotyczących między innymi wolności prasy, ustanowienia centralnego budżetu, kasaty stanowisk zdobytych poprzez koneksje, zakładania nowoczesnych szkół i uniwersytetów, miało uratować gospodarkę w kryzysie. Reform nigdy nie przeprowadzono ze względu na opór dworu cesarskiego ${ }^{30}$.

Podsumowując XIX w., należy wskazać: spadek udziału Chin w globalnym PKB z 28,7\% w 1820 r. do 12,5\% w 1890 r., zmniejszenie udziału w globalnym przemyśle przetwórczym z 33,3\% w 1800 r. do 12,5\% w 1880 r., obniżenie PKB per capita z poziomu 600 USD w 1820 r. do 540 USD w 1890 r. oraz spadek liczby ludności o milion ${ }^{31}$.

W 1905 r. zakończono przeprowadzanie egzaminów do służby cywilnej, a od 1906 r. modernizowano aparat państwa w oparciu o model zachodni ${ }^{32}$. Zwrotem w historii gospodarki przedkomunistycznej Chin okazał się koniec 1911 r., kiedy upadła ostatnia dynastia chińska. Próbując wprowadzić do kraju zasady kapitalizmu, zburzono dawny porządek biurokratyczny i stary reżim. Państwo stało się republika, w której do 1928 r. władzę sprawowały rządy wojskowe (warlordyzm). Pierwszym prezydentem został Sun Yatsen, jednak po 2 miesiącach ustąpił stanowiska zaufanemu współpracownikowi - generałowi Yuanowi Shikai. Za czasów swej dyktatury Shikai (1912-1916) bardziej zależało na utrzymaniu dożywotnio władzy niż na wydobyciu kraju z kryzysu. Przywództwo Shikai okazało się zbyt słabe, dlatego władzę przejmowali stopniowo lokalni działacze. Kraj powoli dezintegrował się $e^{33}$.

I wojna światowa zredukowała wpływy warlordów, co dało impuls chińskim przedsiębiorcom do ekspansji w przemyśle, żegludze, kolei i bankowości. Osłabie-

29 Głównie Wielka Brytania, która pod koniec XVIII w. importowała z Chin 1/7 całej produkcji herbaty, porcelanę, jedwab, wyroby z laki czy leczniczy rzewień chiński. K. Seitz, Chiny. Powrót olbrayma, przeł. T. Mazur, Warszawa 2008, s. 77-78.

30 W. Rodziński, Historia Chin ..., s. 540-557.

31 A. Maddison, Chinese Economic..., s. 158; C. Simmons, De-Industrialization, Industrialization, and the Indian Economy, c. 1850-1947, „Modern Asian Studies” 1984, no. 3, s. 600.

32 K. Seitz, Chiny. Powrót..., s. 134.

33 J. Rodziński, Historia Chin..., s. 615-622. 
nie władzy wykorzystały dwie główne chińskie partie polityczne - Komunistyczna Partia Chin (KPCh) i Kuomintang (KMT), które połączyły siły w działaniach zmierzających do likwidacji władzy warlordów. KMT przejął władzę w kraju dzięki współpracy z KPCh i ZSRR ${ }^{34}$.

W 1928 r. KMT utworzył w Nankinie rząd tzw. Powierzchownej Jedności Chin ${ }^{35}$. Wprowadzono zmiany instytucjonalne dążące do zbudowania społeczeństwa obywatelskiego. Odzyskano autonomię celną i zniesiono podatek od tranzytu, co przyczyniło się do ochrony rodzimego przemysłu oraz złagodziło deficyt budżetowy spowodowany wydatkami militarnymi i zadłużeniem zagranicznym. W Szanghaju powołano bank centralny nadzorujący wszystkie chińskie banki. W 1935 r. przeprowadzono reformę monetarna, w wyniku której srebro zastąpiono nową walutą papierowa. Zmiana ta sprzyjała polityce antyinflacyjnej ${ }^{36}$. Handel zagraniczny nadal w większości finansowały banki zagraniczne ${ }^{37}$. Podjęto próby redukcji wpływów obcokrajowców. Planowano przekształcenia własnościowe na wsiach, ale wysiłki nie przyniosły oczekiwanych efektów.

Władza KMT skupiała się na łagodzeniu wewnętrznych konfliktów, opieraniu się zewnętrznym naciskom i indywidualnym bogaceniu się swoich działaczy. Nakładano coraz wyższe podatki na przedsiębiorców i podnoszono opłaty celne. Natomiast $\mathrm{w}$ reformach pominięto najważniejsze źródło dochodów budżetowych podatek od ziemi. Państwo kontrolowało $2 / 3$ sektora bankowego. Rozluźniono nadzór nad rolnictwem, przekazując podatek gruntowy władzom prowincji. Pogłębiały się dysproporcje rozwojowe. Prowincje wybrzeża stały się centrum gospodarczym kraju, gdzie koncentrowało się około $70 \%$ produkcji przemysłowej $^{38}$. Dalsze egzystowanie „kapitalizmu biurokratycznego" 39 przerwała wojna z Japonia, a potem trzyipółletnia wojna domowa między KMT a KPCh. Inflacja, brak wykwalifikowanej kadry, zamknięcie się na import, coraz słabszy popyt konsumpcyjny, kontrola cen i walki wewnątrz kraju wpędziły Chiny w głęboki kryzys gospodarczy. Ostatecznie po długich walkach 1 września 1949 r. proklamowano

34 Współpraca ta nie trwała długo. W 1927 r. zaniechano jej i dopiero wojna z Japonią (19371945) ponownie połączyła obie partie. J.K. Fairbank, Historia Chin..., s. 259.

35 Jednak rządy nie trwały długo, gdyż przerwał je tzw. długi marsz w celu przejęcia władzy. Zorganizowała go KPCh z Mao Zedongiem na czele. Marsz rozpoczął się w październiku 1934 r., a skończył w październiku następnego roku.

36 A. Maddison, Chinese Economic..., s. 50.

37 P. Lewin, The Foreign Trade Communist China. Its Impact on the World, Praeger Special Studies in International Economics, The Economy Intelligence Unit, New York-London 1964, s. 5.

38 Y. Wei, Regional Inequality of Industrial Output in China, 1952 to 1990, „Human Geography” 1998, no. 1, s. 3.

39 Reprezentowały go cztery rodziny mające powiązania z zagranicą: Chiang Kai-Shek, T.V. Soong, H.H. Kung i Chen Li-fu. Ich fortuny szacowano na 10-20 mld USD. Zmonopolizowały one życie gospodarcze kraju. Przeciwko nim skierowano rewolucję demokratyczną. Economy, China Handbook Editorial Committee, Beijing 1984, s. 1. 
Chińską Republikę Ludową (ChRL), na której czele stanęła KPCh z przewodniczącym Mao Zedongiem.

Pierwsza połowa XX w. nie przyniosła ani znaczącej poprawy sytuacji ekonomicznej Chin, ani przebudowy struktury gospodarki. PKB kraju w 1913 r. stanowił 8,8\% światowego PKB. W 1929 r. jego udział spadł do 6,6\%, a w 1950 r. wyniósł tylko $4,5 \%{ }^{40}$. Pod koniec XIX w. Chiny wytwarzały $12,5 \%$ globalnej produkcji, a w 1938 r. - już zaledwie 3,1\% ${ }^{41}$. W 1949 r. wielkość produkcji przemysłowej Państwa Środka była dwukrotnie niższa niż przed wojną z Japonią. Szczególnie ucierpiał przemysł ciężki, który zanotował spadek o 70\% ${ }^{42}$. Nieznaczny rozwój gospodarczy był rezultatem rozwoju nowoczesnych działów gospodarki, takich jak: przetwórstwo, wydobycie, produkcja elektryczności, transport i komunikacja, chociaż w strukturze PKB nadal dominowało rolnictwo ${ }^{43}$. W alokacji zasobów przeważała konsumpcja indywidualna, która w 1949 r. stanowiła 94\% wszystkich wydatków krajowych. Wydatki rządowe na konsumpcję w skali całkowitych wydatków państwowych stanowiły 4\%, a na inwestycje krajowe netto przypadało 2\%. PKB per capita w 1949 r. wynosił 441 USD, natomiast całkowity PKB w 1950 r. niespełna 240 mld USD. W 1949 r. inwestycje krajowe netto na osobę szacowano na 0,5 USD. W okresie 1900-1950 całkowity PKB powiększył się zaledwie o 10\%, PKB per capita zmalał o prawie 20\% (średniorocznie obniżał się o 0,6\%). Dochód na osobę w 1950 r. wynosił 439 USD i był prawie pięciokrotnie niższy od średniego światowego dochodu per capita (tab. 1).

Do proklamowania ChRL instytucja państwa zajmowała ważną pozycję w gospodarce. Jeszcze na początku 1949 r. KMT National Resource Commission kontrolowała $90 \%$ chińskich złóż żelaza i stali, 1/3 wydobycia węgla, 2/3 podaży energii, 45\% produkcji cementu oraz całe wydobycie ropy naftowej i metali nieżelaznych. Rząd nadzorował najważniejsze banki, wszystkie szlaki kolejowe, samochodowe i lotnicze. Do władz należało 45\% transportu morskiego i śródlądowego, $38 \%$ produkcji w dziedzinie przędzalnictwa, 60\% maszyn tkackich i wiele dużych monopolistycznych przedsiębiorstw handlowych ${ }^{44}$.

40 A. Maddison, The World Economy: Historical Statistics, Development Centre Studies of OECD, Paris 2003, s. 261; L.J. Zimmerman, The Distribution of World Income, 1860-1960 [w:] Essays on Unbalanced Growth, ed. E. De Vries, London 1965, s. 35-56, za: J. Skodlarski, R. Matera, Gospodarka swiatowa..., s. 187.

41 C. Simmons, De-Industrialization..., s. 600.

42 Economy. China Handbook..., s. 2.

43 Sektor agrarny pod koniec XIX w. tworzył aż 68,5\% PKB, w 1933 r. jego udział spadł do 64\%, natomiast w 1952 r. zmalał do około 50\%. A. Maddison, Chinese Economic..., s. 49.

44 Economy. China Handbook..., s. 3-5. 
Tabela 1. Podstawowe wskaźniki demograficzne i makroekonomiczne Chin do 1949 r.

\begin{tabular}{|c|c|c|c|c|c|}
\hline Rok & $\begin{array}{c}\text { Populacja } \\
\text { (mln) }\end{array}$ & $\begin{array}{c}\text { PKB } \\
\text { (mld USD)* }\end{array}$ & $\begin{array}{c}\text { PKB (USD) } \\
\text { per capita }\end{array}$ & Indeks PKB** & $\begin{array}{c}\text { Indeks PKB } \\
\text { per capita** }\end{array}$ \\
\hline 1000 & 59 & 26,6 & 450,8 & 11,0 & 81,7 \\
\hline 1300 & 100 & 60,0 & 600,0 & 24,9 & 108,7 \\
\hline 1400 & 72 & 43,2 & 600,0 & 17,9 & 108,7 \\
\hline 1500 & 103 & 61,8 & 600,0 & 25,6 & 108,7 \\
\hline 1700 & 138 & 82,8 & 600,0 & 34,3 & 108,7 \\
\hline 1820 & 381 & 228,6 & 600,0 & 94,8 & 108,7 \\
\hline 1890 & 380 & 205,3 & 540,3 & 85,1 & 97,9 \\
\hline 1900 & 400 & 218,1 & 545,3 & 90,4 & 98,8 \\
\hline 1913 & 437 & 241,2 & 551,9 & 100,0 & 100,0 \\
\hline 1933 & 500 & 289,2 & 578,4 & 119,9 & 104,8 \\
\hline 1938 & 513 & 288,5 & 562,4 & 119,6 & 101,9 \\
\hline 1949 & 544 & $239,9 * * *$ & 441,0 & 99,5 & 79,9 \\
\hline
\end{tabular}

* W USD w cenach stałych z 1990 r.; ** rok 1913 = 100; *** wartość PKB z 1950 r.

Źródło: obliczenia i opracowanie własne na podstawie A. Maddison, Chinese Economic Performance in the Long Run, Development Centre Studies of OECD, Paris 1998, s. 40, 158; A. Maddison, The World Economy: Historical Statistics, Development Centre Studies of OECD, Paris 2003, s. 160, 162, 172, 179,180, 182.

Gospodarcze relacje międzynarodowe Chin do 1949 r.

W rozwoju chińskiego handlu zagranicznego przed okresem realnego socjalizmu można wyróżnić dwa etapy: pierwszy - przed zdynamizowaniem stosunków handlowych z Europa do XV w. n.e. oraz drugi - podczas intensywnego rozwoju relacji z państwami europejskimi trwającego od XV w. do proklamacji ChRL w $1949 \mathrm{r}$.

Pierwsze kontakty dyplomatyczne z Imperium Rzymskim i Środkowym Wschodem Chiny nawiązały w około I-II w. n.e. W XV-XVI w. zdynamizowano wymianę handlową. Powstały wielkie kampanie, które były korporacjami mającymi monopol w handlu i rządzeniu zagranicznymi terytoriami. Do XVI w. n.e. pozycja geopolityczna Państwa Środka była niezachwiana, dlatego nie zabiegały o poprawne relacje z innymi krajami. Władze Chin, upatrując korzyści w wymianie handlowej z innymi narodami, zezwalały na tworzenie szlaków handlowych pozwalających na sprawne przepływy towarowe między krajem a światem. Szlaki te umacniały status Państwa Środka jako centrum handlu. Ważny w intensyfikacji wymiany handlowej okazał się Jedwabny Szlak. Sieć dróg między Chinami a Europą i Bliskim Wschodem była najważniejszym łączem handlowym na świecie przez wiele stuleci. Wywożono tą drogą nie tylko jedwab, ale również żelazo i papier, natomiast sprowadzano złoto, wyroby jubilerskie i rośliny uprawne. Utrzymywano stosunki handlowe z kalifatami arabskimi, Bizancjum, Indiami, Indonezja, Syjamem, Annamem oraz kupcami żydowskimi 
i syryjskimi ${ }^{45}$. W zależności od panującej w Chinach dynastii państwo cechowało się zróżnicowanym poziomem otwarcia na świat.

Drugie stadium handlu zagranicznego Chin rozpoczęło się wraz z wielkimi odkryciami geograficznymi Europejczyków, rozwojem chińskiego przemysłu i rozbudową żeglugi na początku XV w. Wówczas chwilowo zintensyfikowano wymianę handlowa. Eksportowano jedwab, bawełnę, herbatę i wyroby tekstylne. Ważne miejsce w eksporcie zajmowała ceramika, szczególnie produkcja porcelany. Rozwijał się obrót srebrem, które chińscy kupcy przywozili z Japonii i obu Ameryk. Zgodnie z szacunkami w XVI-XVII w. corocznie wpływało do Chin srebro warte około 10 mln USD ${ }^{46}$. Chiński handel koncentrował się w obrębie Morza Żółtego, Wschodniochińskiego i Południowochińskiego. Dotarto również do wybrzeży Kamczatki oraz nawiązano stosunki handlowe z Portugalia, Hiszpanią, Holandią i Anglią ${ }^{47}$.

Od lat 30. XVI w. zaczęto ograniczać otwarcie Chin. Przyczyną coraz większego zamykania się na kontakty z zagranicą był konflikt między zwolennikami i przeciwnikami utrzymywania relacji gospodarczych z zagranicą. Po długiej walce ideologicznej zwyciężyli oponenci współpracy z zagranica i całkowicie zaprzestano wypraw ${ }^{48}$. Władze Chin przestały traktować wymianę międzynarodową jako czynnik stymulujący rozwój gospodarki. Stosunki ekonomiczne z zagranicą podporządkowano polityce prowadzonej przez rządy absolutystyczne. Ponadto hamulcem w wymianie międzynarodowej okazała się mentalność Chińczyków, którzy byli nastawieni na samowystarczalność i nie wykazywali zainteresowania współpracą z innymi krajami ${ }^{49}$.

Od XVII w. atmosfera prowadzenia handlu zagranicznego pogarszała się. Kolonizacja, wyzysk i agresja mocarstw europejskich w państwach sąsiednich przyczyniły się do stopniowej izolacji Chin od świata i ograniczenia wymiany handlowej. Kontakty towarowe z Zachodem utrzymywano wyłącznie w Kantonie ${ }^{50}$. Oficjalnie decyzja zamknięcia Państwa Środka na świat miała na celu ochronę terytorium przed mocarstwami europejskimi. Faktycznie w dużej mierze wynikała z ksenofobii i antykomercjalizmu cesarstwa. Izolacja z czasem uwydatniła przepaść rozwojowa między Chinami a Europą.

45 P. Curtin, Cross Cultural Trade in World History, Cambridge 1994, s. 105, za: J. Skodlarski, R. Matera, Gospodarka światowa..., s. 57.

${ }^{46}$ J.K. Fairbank, Historia Chin..., s. 179.

47 K.M. Panikkar, Azja a dominacja Zachodu. Epoka Vasco da Gamy w driejach Azji. 1498-1945, Warszawa 1972, s. 66-79.

48 D.S. Landes, Bogactwo i nedza..., s. 120-121.

49 K. Besso, Identities and Security in East Asia, „Adelph Paper” 1999, no. 325, za: S.W. Mosher, Hegemon..., s. 23; J. Rodziński, Historia Chin..., s. 315-316; R. Pyffel, Chiny w roku olimpiady. Państwo Środka od środka, Warszawa 2008, s. 23-25.

${ }^{50} \mathrm{~W}$ handlu kantońskim monopol na wymianę z zagranicą miał cech kupiecki - Kohong. M. Dillon, Dictionary of Chinese History, London 1979, s. 38. 
Mocarstwa europejskie, sprowadzając z Chin wiele niezbędnych dla swoich rynków towarów, wywierały naciski na kraj, aby ponownie się otworzył na handel zagraniczny. Po nieudanych próbach perswazji droga pokojową zmuszono Państwo Środka siłą do otwarcia granic i prowadzenia wymiany handlowej na niekorzystnych warunkach. Obszar kraju podzielono na strefy wpływów. Przegrana pierwsza Wojna Opiumowa (1840-1842) poskutkowała podpisaniem układu w Nankinie w 1842 r., na mocy którego Chiny oddały Wielkiej Brytanii Hongkong, otworzyły 5 portów dla handlu zagranicznego pod nadzorem konsularnym, wprowadziły pięcioprocentowe cło importowe ad valorem oraz zapłaciły wysoką kontrybucję. Inne państwa Zachodu (Niemcy, Francja, Rosja) i Japonia poszły za przykładem Wielkiej Brytanii, także wymuszając na kraju niekorzystne warunki wymiany handlowej. Rozpoczą się okres półkolonializmu.

Klęska Chińczyków w drugiej Wojnie Opiumowej (1858-1860) umocniła pozycję cudzoziemców i poskutkowała kolejnymi niekorzystnymi dla Chin ustępstwami handlowymi oraz otwarciem następnych portów traktatowych (tzw. Treaty Ports). W okresie między sygnowaniem porozumień z Nankinu i Shimonseki w 1895 r. siły traktatowe uzyskały w Chinach liczne przywileje: podlegały eksterytorialnym prawom i jurysdykcji własnych konsulatów. Obcokrajowcy zostali zwolnieni z podatków. Handlowano koncesjami i porozumieniami, a rozwojowi obrotu sprzyjały bardzo niskie cła importowe i brak opodatkowania wymiany handlowej. Wiele instytucji (np. urzędy celne) nadzorowali obcokrajowcy. Sytuacja poskutkowała wysokim deficytem handlowym Chin. Po podpisaniu traktatu Shimonseki Japonia uzyskała pozwolenie na zakładanie w portach fabryk. Z czasem identyczną zgodę wymusiły pozostałe siły traktatowe. Chiny stawały się stopniowo terenem pewnego rodzaju okupacji. Niemcy zajęły Jiaozhou na półwyspie Shandong, Rosjanie - Liaodong i Dalnyj, Brytyjczycy - półwysep Kowloon (przylegający do Hongkongu) i Weihaiwei w zatoce Bohai, Francuzi - Guangzhouwan, Rosjanie przejęli kontrolę nad Mandżuria, Niemcy - nad Shandongiem, Wielka Brytania - nad Yangzi, a Francja miała decydujący głos w Yunnanie. Między 1842 a 1917 r. otwarto 92 porty traktatowe ${ }^{51}$.

Do końca XVIII w. opium oraz bawełna i jej produkty stanowiły $1 / 3$ importu Chin. Natomiast $80 \%$ eksportu generowały herbata $(46 \%)$ wraz z jedwabiem $(34 \%)^{52}$. Większość dziewiętnastowiecznych obrotów handlowych z Chinami kontrolowali Brytyjczycy przez Kampanię Wschodnioindyjska. Z końcem XIX w. chiński wywóz towarów za granicę stanowił niespełna 0,6\% PKB kraju, a głównymi eksportowanymi produktami były: herbata, surowy jedwab i wyroby z niego oraz bawełna. Jednakże udział chińskiego eksportu herbaty w całkowitej wartości wywo-

\footnotetext{
51 A. Maddison, Contours of the World..., s. 165; J.G. Williamson, Globalization and the Poor Periphery before 1950, Cambridge 2006, s. 15; P. Lewin, The Foreign Trade..., s. 5; O. Weggel, Chiny..., s. 75-76; J. Polit, Historia Chin, Warszawa 2004, s. 30.

52 P. Lewin, The Foreign Trade..., s. 7.
} 
żonych produktów stopniowo spadał, czego przyczyną była rosnąca konkurencja ze strony plantatorów z Indii i Cejlonu ${ }^{53}$.

Pod koniec XIX w. przebudowała się struktura chińskiego importu. Poza tradycyjnie sprowadzanymi mało przetworzonymi produktami bawełnianymi i żywnością coraz ważniejszą rolę odgrywało opium, którego udział wzrósł do ponad $1 / 4$ całkowitej wartości importu. Chociaż handel opium został oficjalnie zakazany przez władze chińskie, to narkotyk ciagle przemycano. Opium rozprzestrzeniało się po całym wybrzeżu, a Hongkong przekształcił się w bazę jego składów ${ }^{54}$. Wprowadzenie zakazu handlu narkotykiem doprowadziło do wojen opiumowych między Wielka Brytanią i Francją a Chinami. Kanton utracił status centrum handlu zagranicznego, a jego miejsce zajął Szanghaj ${ }^{55}$.

Wiek XIX i pierwsze dekady XX stulecia cechowała dynamiczna wymiana handlowa z najwyżej rozwiniętymi państwami świata, głównie z Japonia, Wielką Brytanią, USA, a także z Hongkongiem (tab. 2). W latach 30. XX w. do partnerów handlowych Chin dołączyły Niemcy. Rachunek obrotów handlowych Państwa Środka wykazywał deficyt utrzymujący się do połowy XX w. (tab. 3). Po Wielkim Kryzysie spadły obroty handlowe, ale nie doszło do radykalnej przebudowy w strukturze wymiany. Najważniejsze pozycje w chińskim eksporcie zajmowały: jedwab i jego wyroby, soja, olej, jaja, wyroby hafciarskie, surowa bawełna, herbata, wełna, nasiona, rudy żelaza i metale. Kraj z importera stał się największym eksporterem srebra.

Po I wojnie światowej zaniechano przywozu opium, które dotychczas stanowiło główny produkt importowany. Znacznie zmalał import tekstyliów na rzecz papieru, nafty, wyrobów wełnianych i bawełnianych, paliwa i benzyny, drewna, cukru, maszyn tekstylnych, samochodów, ciężarówek, części zamiennych, tytoniu, żelaza, stali i wyposażenia kolejowego. Do 1936 r. struktura importu coraz bardziej koncentrowała się na surowcach niezbędnych do rozwoju przemysłu ciężkiego. Sprowadzano coraz więcej żelaza, stali, metali, farb i produktów przemysłu chemicznego (tab. 4).

W wyniku okupacji japońskiej i II wojny światowej obroty handlowe w $1946 \mathrm{r}$. spadły siedmiokrotnie w porównaniu z $1937 \mathrm{r}^{56}$ Po II wojnie światowej Chiny stały się mało znaczącym w świecie partnerem handlowym. Większość wymiany handlowej kraj realizował w ramach eksportu do Organizacji Narodów Zjednoczonych ds. Pomocy i Odbudowy.

53 A. Maddison, Chinese Economic..., s. 51.

54 W. Rodziński, Historia Chin ..., s. 442.

55 Wartość eksportu Szanghaju w 1852 r. stanowiła połowę całkowitego chińskiego eksportu. Natomiast Kanton traktowano wyłącznie jako ośrodek utrzymywania kontaktów, jak to określano, z ,zamorskimi barbarzyńcami”. J.K. Fairbank, Trade and Diplomacy on the China Coast, Stanford 1969, s. 393.

56 J. Skodlarski, R. Matera, Gospodarka światowa..., s. 207. 


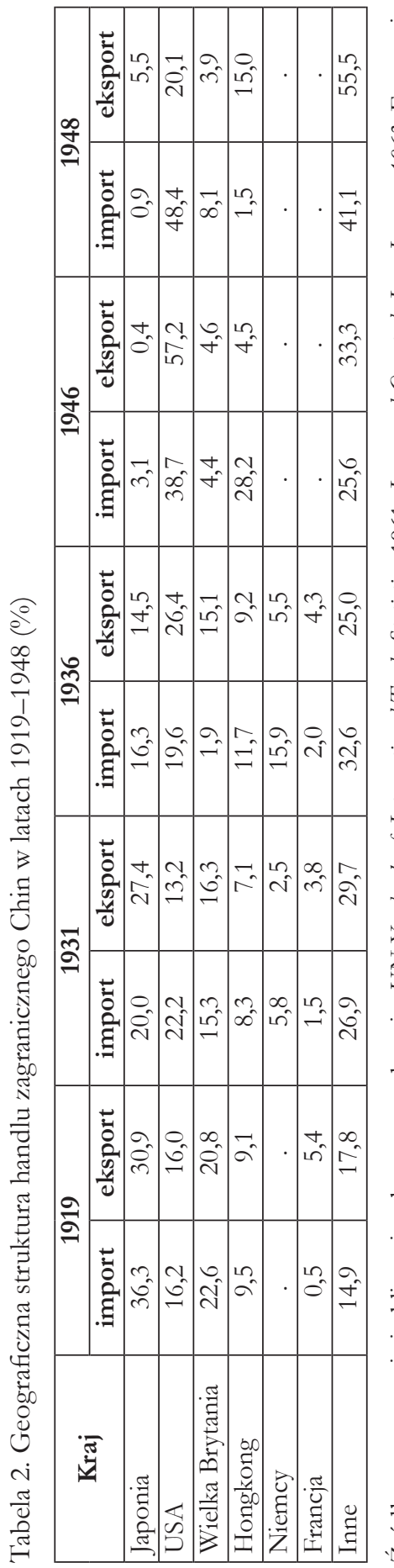

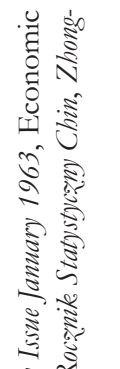

늘

요요

हैं में

अ

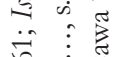

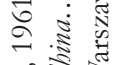

) 0

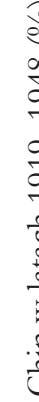


Tabela 4. Struktura chińskiej wymiany towarowej w latach 1925-1936 (\%)

\begin{tabular}{|c|c|c|c|c|}
\hline Import & 1925 & 1928 & 1931 & $1936^{*}$ \\
\hline Produkty bawełniane & 16,3 & 14,2 & 7,6 & 1,5 \\
\hline Przędza bawełniana & 4,4 & 1,6 & 0,3 & 0,2 \\
\hline Surowa bawełna & 7,4 & 5,7 & 12,6 & 3,8 \\
\hline Zboża & 6,8 & 5,7 & 10,6 & 4,1 \\
\hline Mąka pszenna & 1,6 & 2,6 & 2,0 & 0,5 \\
\hline Cukier & 9,5 & 5,6 & 6,0 & 2,2 \\
\hline Paliwa płynne i nafta & 7,9 & 10,8 & 6,3 & 8,3 \\
\hline Produkty transportowe & 1,9 & 2,3 & 2,3 & 5,6 \\
\hline Produkty przemysłu chemicznego i farby & 5,6 & 7,5 & 8,0 & 10,8 \\
\hline Żelazo, stal i metale & 4,7 & 5,4 & 6,2 & 13,2 \\
\hline Maszyny & 1,8 & 1,4 & 3,1 & 6,4 \\
\hline Pozostałe & 32,1 & 37,2 & 35,0 & 43,4 \\
\hline \multicolumn{5}{|l|}{ Eksport } \\
\hline Jedwab i jego produkty & 22,5 & 18,4 & 13,3 & 7,8 \\
\hline Herbata & 2,9 & 3,7 & 3,6 & 4,3 \\
\hline Soja** & 15,9 & 20,5 & 21,4 & 1,3 \\
\hline Nasiona i olej & 7,9 & 5,8 & 8,4 & 18,7 \\
\hline Jaja i ich produkty & 4,3 & 4,4 & 4,1 & 5,9 \\
\hline Skóry & 4,0 & 5,4 & 4,1 & 5,7 \\
\hline Rudy żelaza i metale & 2,9 & 2,1 & 1,6 & 7,7 \\
\hline Węgiel & 2,6 & 2,9 & 3,0 & 1,6 \\
\hline Bawełna i jej produkty & 5,8 & 7,2 & 7,8 & 7,0 \\
\hline Pozostałe & 31,2 & 29,6 & 32,7 & 40,0 \\
\hline
\end{tabular}

* bez Mandżurii; ** 20\% realizowała sama Mandżuria

Źródło: opracowanie własne na podstawie Yu-Kwei Cheng, Foreign Trade and Industrial Development of China, za: P. Lewin, The Foreign Trade Communist China..., s. 7-8.

Chiny jako kraj niestabilny ekonomicznie i politycznie nie przyciagały wielu inwestorów zagranicznych spoza tzw. bloku sił traktatowych, do którego zaliczano Wielką Brytanię, Japonię, Francję, Niemcy i Rosję oraz USA. Wymienione mocarstwa i Mandżuria odgrywały znaczącą rolę w gospodarce Chin, o czym świadczyła ich obecność w przemyśle i dominacja w handlu zagranicznym. W latach 30. XX w. przedsiębiorstwa zagraniczne wytwarzały 18,8\% wartości dodanej przemysłu, przedsiębiorstwa należące do Mandżurów - 14,2\%, natomiast chińskie zakłady $-67 \%$. Cudzoziemcy nie interesowali się rolnictwem - wkład przedsiębiorstw zagranicznych w wartość dodaną sektora nie przekraczał 2,5\%. Najwyższy udział zagranicy występował w: przemyśle tekstylnym - około połowa produkcji; żeglu- 
dze - ponad 50\%; kolei - 1/3 linii kolejowych i wydobyciu węgla - ponad połowa pochodziła z przedsiębiorstw zagranicznych lub spółek chińsko-zagranicznych ${ }^{57}$.

$\mathrm{Na}$ początku XX w. inwestycje zagraniczne skierowane do kraju wynosiły 0,92 mld USD, a w 1914 r. wzrosły do 1,78 mld USD. W 1931 r. do kraju napłynęły bezpośrednie inwestycje zagraniczne o wartości 2,5 mld USD, z czego najwięcej (26\%) skierowano do działalności transportowej, 15\% do przedsięwzięć handlowych, 12\% do branż przetwórczych, a 7\% do sektora bankowego i finansowego. Kapitały zagraniczne trafiały głównie do miast portowych, w tym do Szanghaju. Najważniejszymi dostawcami kapitałów zagranicznych byli: Wielka Brytania (37\%), Japonia (35\%), USA i Francja (po 6\%). Kapitał obcy w 1936 r. tworzył prawie $1 / 3$ wartości dodanej sektora finansowego ${ }^{58}$. W 1936 r. inwestycje oszacowano na 2,68 $\mathrm{mln} \mathrm{USD}^{59}$.

Handel zagraniczny Chin do 1949 r. kształtowały decyzje polityczne, a nie determinanty ekonomiczne. W historii kraju występowały okresy zintensyfikowanej wymiany międzynarodowej i lata częściowego zamykania się na współpracę handlową ze światem. Decyzje o wzmożonej lub ograniczonej wymianie handlowej z innymi narodami wynikały niejednokrotnie z postawy cesarza i jego najbliższych współpracowników. Władcy przychylni obcokrajowcom, popierający przywożone przez nich nowinki technologiczne i naukowe oraz towary niedostępne na wewnętrznym rynku wspierali handel zagraniczny i dostrzegali wiele jego zalet dla rozwoju kraju. Z kolei ksenofobiczni cesarze traktowali Chiny jako Niebiańskie Królestwo, które nie potrzebowało utrzymywać kontaktów z innymi krajami. Jednak nietrudno zauważyć, że w okresach zamykania się na świat gospodarka Chin podupadała i następował zastój w rozwoju.

\section{Podsumowanie}

Zaprezentowane w artykule poszczególne etapy rozwoju chińskiej gospodarki i jej powiązań ze światem przed okresem proklamacji ChRL ukazują silną współzależność między kondycją gospodarki a decyzjami politycznymi. Te ostatnie w dużej mierze determinowały kierunki i dynamikę rozwoju Państwa Środka. Także postawa społeczeństwa zamknięta na współpracę międzynarodową oraz często brak zrozumienia i ignorancja procesów zachodzących w gospodarce światowej były przyczyną wprowadzania niekorzystnych dla rozwoju strategii gospodarczych.

57 K. Chao, Capital Formation of Cotton Textile Production in China, Cambridge 1977, s. 301-307; T.C. Liu, K.C. Yeh, The Economy of the Chinese Mainland: National Income and Economic Development, 1933-1959, Princeton 1965, s. 143, 428.

58 T.C. Liu, K.C. Yeh, The Economy ..., s. 604.

59 C.M. Hou, Foreign Investment and Economic Development in China 1840-1937, Cambridge 1965, s. 13; P. Lewin, The Foreign Trade..., s. 6. 
Historia gospodarki Chin sprzed 1949 r. stanowi unikatowy i trudny do wyjaśnienia przypadek nagłego upadku mocarstwa. W zależności od opracowań wyróżnia się zewnętrzne i wewnętrzne przyczyny schyłku potęgi kraju. Wśród czynników zewnętrznych za decydujące należy uznać wtargnięcie obcych mocarstw na teren Państwa Środka i jego eksploatację ekonomiczną na wielu płaszczyznach. Za główny wewnętrzny czynnik rozkładu potęgi kraju należy uznać nieodpowiednio prowadzona politykę gospodarcza, skostniałe zasady administracyjne oraz protekcjonizm okresami przechodzący w autarkię. Dowodem na znaczną rolę prowadzonej polityki w rozwoju gospodarczym były lata panowania ksenofobicznych cesarzy, kiedy państwo stopniowo wyniszczały kolejne nietrafione decyzje władców, między innymi zamknięcie na handel zagraniczny bez żadnego ekonomicznego uzasadnienia.

W znacznej mierze o upadku Chin zadecydował brak zdolności do wykorzystania potencjału tego kraju. Z przytoczonych w artykule przykładów wynika, że poziom rozwoju naukowo-technicznego Państwa Środka znacznie przewyższał resztę świata. Wiele wynalazków znalazło bezpośrednie zastosowanie w gospodarce i intensyfikowało produkcję, np. rolniczą. Niestety, część chińskich wynalazków okresu starożytności i średniowiecza zapomniano, a wielu z nich nie upowszechniono. Także brak wolnego rynku stanowił hamulec dla rozwoju gospodarki. Natomiast ortodoksyjne wartości wyznawane przez społeczeństwo bardziej sprzyjały regresowi niż akumulacji know-how. Jednak nie udało się wyeliminować Chin z areny międzynarodowej. Po okresie zapaści gospodarczej kraj podją próbę odbudowy swej pozycji w systemie światowym w połowie $\mathrm{XX}$ w.

\section{SUMMARY}

\section{THE HISTORY OF CHINA'S ECONOMIC PRE-COMMUNIST PERIOD. THE TRANSFORMATION OF INTERNAL AND INTERNATIONAL ECONOMIC RELATIONS}

The aim of the article is to present the different stages of development of the Chinese economy and its links to the global economy. In the history of the pre-communist Chinese socioeconomic development (before $1^{\text {st }}$ October 1949) we can distinguish two stages. The first stage covers time from $221 \mathrm{r}$. BC to the beginning of the $19^{\text {th }}$ century AD, when China's economy based on agriculture and pursued policies focused on military expansion. The second stage lasted since the industrial revolution began in Europe till the proclamation of the People's Republic of China in 1949. In terms of international economic relations development, economic history can be divided into two stages: before trade intensification with Europe - to the $15^{\text {th }}$ century $\mathrm{AD}$ and during the intensive development of relations with European countries since the $15^{\text {th }}$ century to the proclamation of the PRC. 